\title{
Current issues concerning education for democracy in Hungary
}

\author{
JÓZSEF KAPOSI*
}

Pázmány Péter Catholic University, Faculty of Arts, Centre for Teacher Training, Budapest, Hungary

\section{RESEARCH PAPER}

Published online: October 29, 2020

(C) 2020 The Author(s)

\begin{abstract}
The importance of preparation for citizenship has been recognized for millennia, while education for democracy has been central to pedagogical thinking in Europe and in Hungary for more than a quarter of a century (Crick Report, European Year of Citizenship through Education, EU key competences, modified version of the NCC). Educating a citizenry that is capable of thinking independently, is equipped with critical skills and can deliberate about matters appears in these documents as a definitive goal. The concept of civic competence or citizenship competence indicates a combination of such knowledge, skills, abilities and values that make the individual capable of effectively participating in an everyday life that is based on democratic values as well as in civic society (Hoskins and Crick, 2008, cited by Kinyó, Az állampolgári kompetencia egyes összetevöinek és a közösségi tevékenységformák jellemzöinek vizsgálata 7 . és 11. évfolyamos tanulók körében $[\mathrm{PhD}$ dissertation: Individual Components of the Competence of Citizenship and an Examination of the Characteristics of Forms of Community Activities Among Students in the 7th to 11th Grades], 2012). The various models of preparation in schools assume that civic knowledge has identifiable elements that can be taught (e.g. texts of legal documents, constitutional principles, the structure of the state); at the same time, civic "knowledge" comprises rather the adoption of attitudes and the practice of certain skills. This study, supported by research data based on survey questions, seeks to discover the degree of prevalence of education for democracy and citizenship in everyday practice, as well as the kinds of problems those affected see in this area and what recommendations they have to address these difficulties.
\end{abstract}

\section{KEYWORDS}

citizenship competences, active citizenship, education for democracy, student council, cooperation-competition, students' voice

\footnotetext{
*Corresponding author. E-mail: kaposij@gmail.com
} 


\section{INTRODUCTION}

Various theories have been formulated to explain the factors that allowed the European continent to advance ahead of the other parts of the world in the Middle Ages. According to one wellknown theory (Gunst, 1996; Stevenson, 2005), the general acceptance of the system of private ownership, founded on individual interests and supported by the Roman legal system, and - in a decisive manner - the establishment of a system of power-sharing, played an important role in this advancement, in addition to the spread of Christian teachings (e.g. love, mercy, equality before God). Early on, this power-sharing was between profane powers and the church, but later expanded with the appearance of autonomous cities and feudalism, and it gained new momentum with the spread of the Reformation, the penetration of the Protestant ethic (Max Weber, 2020) and the acceleration of the transformation into a civil society. The main characteristic of the "Western paradigm" of power-sharing is "separation of society and the state" (Szücs, 1983) which means that society is, to a degree, independendent from the power of the state and exists in an autonomous manner. ${ }^{1}$ The principle of power-sharing was also laid down in the rules of the Enlightenment (Körösényi, 2004: 61) in the interest of ensuring the rights of the individual against those of the state (despotism). ${ }^{2}$ The spread of political rights makes possible and necessary the birth of the self-conscious and civilized everyman, otherwise called the citizen, who is not only an active shaper of his own fate but of public life, too, while, by means of the rule of law, "enjoying the protection of the state of person and property" (Szabó, 2016: 346).

Because of the spread of political rights, so-called civic education was given particular emphasis in the political democracies that took shape in modern states operating in the public interest and introducing universal mandatory school education in the course of the 18th and 19th centuries. Since then, an indispensable element of almost all education systems that can be called modern and founded on European principles is preparing the citizens of tomorrow for the practice of civic affairs. With a past going back more than 200 years, the content and methods of institutional civic education based on the Western European paradigm show an extraordinary degree of diversity in terms of period and region. But common to all is that they are based on some foundation of state philosophy and they mainly strive to prove the advantages of that type of state represented in the teachings thus formulated. Additionally, such content is presented that shows the state organization of the given country in the interest of involvement in public affairs. Educational programmes - practically from the start - have concentrated, without exception, on the attitude expected of citizens resulting from the system of values of the given society, in addition to the provision of knowledge.

\section{INTERNATIONAL OUTLOOK FROM THE TURN OF THE CENTURY TO THE PRESENT}

The appreciation of teaching civics in schools began to grow at the end of the 1990s, thanks to the driving force of the Council of Europe which launched the education for democracy

\footnotetext{
${ }^{1}$ Jenő Szücs has called this state of being a "luxury product of history"

${ }^{2}$ The three branches of state power, the legislature, executive and judiciary, "may not come under the control of the same persons or body".
} 
programme. Most countries in the developed world are committed to social studies and education for citizenship, and in recent years these competences and their assessment have been handled as a priority by the IEA (International Association for the Evaluation of Educational Achievement), too. Of special interest with regard to the topic is the so-called Crick Report ${ }^{3}$ which clearly states that the teaching of democracy is about much more than acquiring knowledge of current political affairs. It sets as a goal educating a citizenry of independent thinkers with critical skills and the ability to think analytically, whose members can positively influence public life through fairness and objectivity (Huddleston, 2002).

A milestone of this European-level initiative was the proclamation of 2005 as the "European Year of Citizenship through Education". ${ }^{4}$ Connected to this, a consensus agreement by a research group ${ }^{5}$ dealing with the issue of active citizenship defined the combination of knowledge, abilities, attitudes and values understood as civic competence or citizenship competence that make individuals able to more effectively participate in an everyday life based on democratic values and in civil society (Hoskins - Crick 2008, as quoted by Kinyó, 2012). This all means that the system of goals of education for citizenship in an international dimension is determined rather by the stress on democratic values, although some countries - befitting their own situation - place further emphasis on one thing or another (e.g. security policy, the strengthening of civil society and the acknowledgment that one of the defining conditions for effective education for citizenship is the microcommunity: the family, the school, the local society) (Strategy, 2009: 5).

In countries with a strong democratic heritage, two basic models for education for citizenship have developed. The American one "primarily stresses the importance of participation in public life beside a presentation of the system of democratic institutions", and the German model "considers important rather the formation and development of a critical attitude toward socialpolitical phenomena" (Gönczöl, 2001: 178). Both of the aforementioned models are based on the premise that civic knowledge has identifiable elements of knowledge which can be learned and taught (e.g. texts of legal documents, constitutional principles, the state organizational structure and the tools of everyday civic administration). At the same time, civic "knowledge" is the product rather of certain abilities and attitudes, and its essence means rather the ability to act.

The novel characteristics of education for democracy are, first, its alignment with the competences of lifelong learning; second, the central focus on strengthening social integration and social cohesion; and third, the implementation of competency-based thinking. As a result of this, civic competences and broad standards are presented as recommendations. Fourth is the stress on viewing the entire process of education as part of a complex way of thinking to solve social problems based on the premise that "social issues must be thought of in systems that are multidimensional and complex; that is, we must recognize that there are multiple actors, interests

\footnotetext{
${ }^{3}$ On the basis of the recommendation of the Crick Committee, citizenship has been taught as an independent subject in England since 2002

${ }^{4}$ The driving force for this was the Council of Europe which launched a program for education for democracy at the end of the 1990s, and one of the milestones of this program was the proclamation of 2005 as the "European Year of Citizenship through Education".

${ }^{5}$ The definition of the expression citizenship competence is based on the conclusions of the section of CRELL (Centre for Research on Lifelong Learning) dealing with research related to active citizenship, while the theoretical guidelines of the IEA studies are used for the description of the social-cultural context of the theoretical framework.
} 
and alternatives present, and this complexity requires treatment that is equal parts cognitive and visceral" (Halász, 2005).

According to one of the latest European surveys, education for citizenship is present in all countries, in national, regional or local public education programs (Eurydice, 2017). These countries have defined the goal of this education in a variety of ways, but most often it is to make young people active citizens who are able to contribute to the wellbeing of society. In most countries, not only objective knowledge is required, but stress is also placed on the development and deepening of skills, attitudes and values. The topics discussed, the focuses of education for democracy vary (topics may include the principles of democratic society, social issues, cultural diversity, sustainable education and the European and international dimension). Education for citizenship is generally understood to involve mastering four different areas: critical and analytical thinking, political literacy, attitudes and values, and active participation (Eurydice, 2012, 2018). It can also be established that the impact of the family is present in almost every document, while significant emphasis is placed on the socializing role of the school and its models for preparing students for public life, and furthermore activities conducted in local communities and the civil sphere.

The so-called whole-school approach (Council of Europe, 2018) shows the complex system of education for democracy and citizenship in which three priority areas are designated in the scholastic sphere from the point of view of effective education for democracy: Teaching and learning methodology; Operation and fundamental principles of school administration; and Cooperation with the community. The concept outlines important conventions related to the operation of schools that follow from the three aforementioned areas. A priority goal in the framework of Teaching and learning methodology is establishing a safe (student-friendly) classroom community where students can freely express their opinions, share their points of view, and participate in shaping and complying with rules for operation. This involves the creation of a kind of learning environment and atmosphere in which cooperative learning forms can be brought to the forefront; in which varying student and teacher cooperation (assessing each other's practices, fleshing out practices together, cooperation in implementation) is ensured. Access to projects important for students and to the related content, to exposure to alternative means of interpretation, and to the consideration and discussion of various perspectives is also ensured. This is rounded out by requiring that students have the opportunity to participate in decisions that affect them at group or institutional level. In the area of Operation of school administration, school heads and administrators are expected to take into account all affected interests; to implement fully the principles of human rights, equality and responsibility; and to involve affected groups in decision-making. With regard to institutional rules and procedures, the system of oversight must be handled with a close eye to upholding civic and human rights, and this principle must also be applied to new rules. Students' participation is of key significance in these processes: assuring the expression of their opinions and genuine participation in decision-making, and establishing the institutional framework necessary to achieve this. The main aim of cooperation with the community is involving parents and the local community and using local resources and connections, as well as drawing students' attention to local social problems. Of key importance is cooperation with other schools in the areas of experience and resource-sharing, with the aim of achieving mutual understanding with communities with divergent cultures and in the interest of approaching cultural questions and global problems from multiple viewpoints. Also important is cooperation between local institutions 
and organizations, for example between local government officials and institutions, religious organizations, minority groups and organizations defending legal rights.

\section{HUNGARIAN REGULATION 1995-2012}

Education for citizenship and democracy was given two emphasized sections in the common requirements of the 1995 National Core Curriculum (NCC, 1995) entitled Country and Folk Studies, and Connecting to Europe and the Whole World. In the former was formulated, among other things, that "National consciousness should be established, national self-knowledge and love of country deepened, and the exploration and fostering of our historical, cultural and religious memories and tradition, in a narrow and a broader sense, should be encouraged" (NCC, 1995). In the latter, it was stated that "A positive relationship to common European values should be shaped in students. Students should have an appreciation of the results achieved in the course of European development, including Hungary's related role and contribution" (NCC, 1995). The details presented show that the stated goals basically prefer learning and processing national and European traditions and cultural heritage, while stressing the necessity of connecting this duality. This demonstrates well the strengthening, in a cognitive and visceral sense, of belonging to Europe, of identifying with the way of life and spirit of the developed West. The following appeared as learning goals in the subject area of The Person and Society: "the strengthening of the national and civic consciousness, social sensitivity. . .openness to the problems of society. . establishment of skills and abilities on which the knowledge and skills necessary to make use of the democratic system of institutions are based. . conscious participation in democratic public life..." (NCC, 1995: 84).

The Matriculation Requirements (Matriculation Decree 1997) drafted at the beginning of the 2000s stated of the evaluation of examination goals for the subject of history that they shall determine "...whether the examinee has mastered the skills and knowledge with which he or she can interpret historical events and phenomena; whether the examinee can use his or her historical knowledge to interpret contemporary social phenomena" (Matriculation Decree 1997). Fundamental Citizenship Studies: The study of human rights and presentation of the principles of legal equality, Citizens' rights and responsibilities was included under the topic Contemporary Hungarian Society and Way of Life in the detailed matriculation requirements for the subject of history (Ministerial Decree 2002). Additionally, there is the topic The Operation of Parliamentary Democracy and Autonomy, which includes the sub-topics The Election System and The Tasks, Organization and Operation of Local Governments; and, at the elevated level, complemented by Hungarian Constitutionality, its Elements (e.g. the institution of constructive mistrust, referendums) and Institutions (e.g. Constitutional Court, the institution of the ombudsman).

The spirit, system of goals and theoretical approach of the 1995 NCC remained unchanged at the time of the 2003 amendment of the NCC (NCC 2003). The topic Connecting to Europe and the Whole World appeared with a new title: Awareness of European Identity - Universal Culture. In the ' 95 version, only European values appeared, but in the amended NCC it was stated that students "become European citizens while preserving their Hungarian consciousness"; additionally, there is a literal reference to students who "will live their adult lives as citizens of the European Union" (NCC, 2003). The fundamental principles and goals of the subject area 
The Person and Society remained basically unchanged. Naturally, new motifs appeared, too; for example social studies now helped to create greater sensitivity to social problems in students "and develop skills necessary for conflict resolution" (NCC, 2003). The document set as a goal shaping the behavioral forms of democratic civic existence and "strengthening the national identity, historical and civic consciousness" (NCC, 2003).

The 2007 version of the NCC (NCC 2007) served to include common European key competences ${ }^{6}$ necessary for lifelong learning, on the recommendation of the Council of Europe. As a result, the key competences, "interpersonal, intellectual and social, as well as civic competences" (Vágó \& Vass, 2006: 199) were placed at the top of priority development goals in the document. From the point of view of education for citizenship and democracy, there emerged "Social and Citizenship Competence" which included value-based community integration as well as the necessity of orientation in diverse social contexts. Study of this key competence involved considering documents with important significance (e.g. the Charter of Fundamental Rights of the European Union), connections to the events of national, European and world history, and the institutional system of European integration. Among the skills stressed were proficiency in public affair and the necessity of participating in community activities and in decision-making. It lists those positive attitudes which are necessary for the exercise of civic activities, for example respecting religious and ethnic diversity, sense of responsibility, constructive participation, effective communication, cooperation and self-confidence.

The 2012 version of the NCC (NCC 2012) defined itself as novel, but in reality was not an entirely new document, rather only a new version of the curriculum. The document shows continuity on a number of points, not only with the ' 95 version, but with earlier versions, too. It even returns to the fundamental principles of the ' 94 version, affirming that students connect to the cultural sphere of European civilization while preserving their Hungarian consciousness (NCC Principles 1994). This continuity is reflected in a number of earlier accepted fundamental principles: the exercise of general and fundamental human rights, complemented by the focus on human dignity and the repudiation of violence, and furthermore equity are established as requirements. Additionally, the structure of the introduction of the document - there appear Common Requirements (now Developmental Areas - Education Goals) and European Key Competences, reinforcing each other, and the labeling of Areas of Literacy is also evidence of a kind of continuity. (Kaposi, 2013: 89) A novel element is that establishing a balance between civic rights and responsibilities as well as harmony between individual goals and the common good is made a priority task for schools, while respect for the law and compliance with the rules of coexistence is seen as a defining criterion for citizenship. There appears in the text a marked intention to instill love of country and from this comes the requirement of "defense of Hungary" as a new civic responsibility, which, according to the authors of the text, does not mean military service, but individual contributions to dealing with catastrophes that threaten the community (fire, flood, etc.). (Kaposi, 2015: 148) Developmental Areas - Education Goals has been supplemented with a section called "National Consciousness, Patriotic Instruction" in which preserving national and folk culture values and traditions as well as knowledge of the work of important Hungarian historical figures, scientists, inventors and artists are set as objectives. Preparation for the integrative approach and education for citizenship present in the NCC's

${ }^{6}$ Developmentof these so-called Key Competences became a development priority in EU policy. 
People and Society area of literacy is applied in the teacher certification requirements, too. "The goal of training [is to make teachers capable] of teaching subjects in history and civic studies [so] they can integrate their subject and pedagogical-psychological knowledge, that they [may be] capable of planning, organizing and managing the teaching-learning process of history and civic studies, and of shaping students' history and civic literacy, skills and abilities." (Ministerial Decree 2013). Furthermore, the following competences to be mastered in the course of training appear: "Acceptance of the value of democracy, acknowledgment and acceptance of the importance of active citizenship, and respect for individual and human rights." (Ministerial decree 2013)

If we look back on the last quarter century of Hungarian regulation of curriculum content from the point of view of education for democracy, we see that requirements - independent of the course of education policy - put faith in education for democracy and so-called active citizenship and are in line with international trends. This is especially true if we look at the professional pedagogical literature, in which such statements are characteristic: "democratic thinking is also constructed from the smallest cognitive building blocks, thus shaping and developing these abilities require the practice of such activities in schools in a number of different contexts" (Csapó, 2000; Mátrai, 1999). In light of all this, it would appear difficult to explain research and analyses - in large part conducted in secondary schools - in recent years that report on "withdrawal" (Gazsó \& Stumpf, 1995), on disinterest in public life, and, ultimately, on the ineffectiveness of democratic education (Csákó, 2011). For this reason, we were curious to find out what students in the upper grades of primary school and the lower grades of secondary school, as well as the teachers and administrators there think about ongoing education for citizenship in their own schools and the practice of developing democratic skills and attitudes.

\section{THE BACKGROUND AND FOUNDATIONS OF A DEVELOPMENT}

With regard to the centrally-developed so-called Education for Democracy Project Day, ${ }^{7}$ there was an opportunity in the spring of 2018 to gauge with an online survey - in the framework of a predetermined, representative sample - the opinions of students, teachers and administrators on ongoing citizenship/democracy education and on their opportunities to become involved in public affairs. ${ }^{8}$ From the point of view of recognizing and applying democratic values, schools are a "priority platform", as it is here that students can master those democratic forms and advocacy models that can be applied later in their broader environments. The survey was basically intended to map out to what degree the complex system of education for democracy and citizenship, and the so-called whole-school approach (Council of Europe, 2018) was being applied, as well as identify problems the actors saw in this area and how curriculum requirements were being met. Hungarian education policy attaches great importance to the central

\footnotetext{
${ }^{7}$ The development of the thematic days and weeks at the Educational Authority took place in the framework of the Creation and renewal of innovative classroom management procedures and digital developments serving the purpose of assessment and evaluation related to the framework system of public education (EFOP-3.2.15-VEKOP-17-2017-00001) project. Zsolt Korpics participated as a developer and editor in the creation of the thematic days and online training program prepared in the framework of the project.

${ }^{8}$ The survey was put together by Janka Kalocsai and she prepared the report (manuscript), the data of which support the other parts of the paper.
} 
curricula, evidenced by the fact that these rules have undergone a significant overhaul four times in the past 30 years. This is why the survey dealt with expectations appearing in the curricula in detail. At the same time, the results also show that the role of rules at the level of individual schools is declining. The student survey was completed by close to 900 young people between the ages of 13 and $16,{ }^{9}$ while almost 120 school staff filled out the teachers' survey. ${ }^{10}$ The online survey asked mainly for statements to be ranked, rated or evaluated, but some elements offered respondents the opportunity to express answers.

The survey - according to requirements laid down in rules on content - asked about the practice in schools of the teaching of civic studies, about an assessment of the necessity of the Education for Democracy Project Day, and about institutional characteristics, circumstances and attitudes, apparent or "veiled", which influence in an essential manner the recognition and acceptance of the democratic way of thinking and system of rules. The questions on practice in schools focussed on four areas: 1. the preferred pedagogical goals and the characteristics of classes in the institution; 2. the school subjects of education for democracy, an assessment of the Democracy Project Day; 3. the characteristics of school life: the areas in which students express their opinions, school decision-making and the operation of the student self-government (DÖK); 4 . opportunities for a more democratic school operation, being informed about public affairs and opportunities and areas in which to respond.

With a view to the preferred pedagogical goals, educating children to be honest and sincere was at the top of the ranking for teachers and school principals, followed by the establishment of a good school atmosphere, education for a healthy lifestyle, drawing out children's abilities, fostering national traditions and awareness of rules. The lowest-ranked and least implemented goal was establishing a task-oriented atmosphere, encouraging students to express their opinions and the development of questioning. It is certainly telling from the point of view of education for democracy that pedagogical practices that aim to develop skills of such importance as critical thinking and the ability to express opinions ended up in last place in the ranking by teachers/ school administrators.

The survey of pedagogical practices shows that the long-awaited pedagogical culture shift has hardly taken place. Students, school administrators and even teachers themselves responded that pedagogues apply frontal method in classes, most often "the teacher stands by the blackboard and says what must be learned" (Kalocsai, 2018) - as students have put it. It is welcome, however, that the proportion of tasks solved in group work is visibly growing. Contradicting themselves, however, the majority of pedagogues are of the opinion that students "learn the most if they find the solutions to problems themselves" (Kalocsai, 2018). Certainly a number of motives can be identified as the reason for this contradiction, but perhaps the most likely is that facilitator tasks appearing in the new pedagogical requirements mean more work for most teachers,

\footnotetext{
${ }^{9}$ Among the 899 respondents to the student survey, almost two-thirds were youth between the ages of 13-16; the ratio of boys and girls was about $50-50 \%$.

${ }^{10}$ The pedagogues' survey conducted in the project day schools was filled out by 118 teachers, mostly (82\%) women, about half with college degrees and half with university diplomas and close to $50 \%$ with 25 years of work experience. More than $80 \%$ of the respondent teachers worked in the lower or upper classes of primary school, and most taught history. The administrators' survey was completed by 69 (43 men and 24 women) school heads with an average age of over fifty; the share of those with college and university degrees was about equal. Almost $60 \%$ of the respondent administrators had managed administrative tasks in their current institutions for 3-10 years.
} 
because this necessitates extra preparation and that is why they cling to the role of knowledge transmitter. This outlined practice is also problematic because the successful exercise of democratic skills is seen in the pedagogical literature as an interactive and productive task of the students. It would certainly help to transform the culture of pedagogical methodology to a large degree if the dominance of competence-based education were to prevail, if cooperative learningteaching tools and collaborative techniques would be brought to the forefront, and if the use of the project method would gain greater traction.

The curricular program from education for citizenship and democracy appears mainly (about $80 \%)$ integrated with the subject of history, and is implemented mostly in that framework. Teachers have expressed the education goal of civic/social studies - essentially in line with curriculum requirements - to form a feeling of responsibility for the community, to strengthen critical thinking, and to develop tolerance. Among the topics recommended in the curriculum, the least stress is placed on learning about the operation of the system of political institutions, as is shown by students' ranking of topics most frequently covered: 1 . concept and tools of democracy (65\%), 2. minorities, national minorities (56\%), 3-3. forms of political participation, election system (31\%-31\%) (Kalocsai, 2018). The ranking of the topics, or at least the content stressed in classroom processing is generally accepted by students, even though there is some contradiction with the topics they indicated as important and worth covering in their answers (e.g. topics related to social position, social equality, social responsibility, solidarity, and citizens' rights and responsibilities). All of this would indicate that students know the most important ethical principles of a functioning democratic society, even though they consider the principles themselves as more important than the tools necessary to apply them, the assurance of a chance for political participation or an understanding of the how the election system works. Or do they not believe in applying these in practice on the basis of their experience?

Most teachers and school administrators judged the organization and implementation of the project day targeted at education for democracy worth supporting. According to their views, they encounter significant gaps in students' knowledge in this area. They consider the appearance of the following curricular content to be necessary: practices that aim to develop various democratic skills, such as a culture of debate and the development of expressing opinions, the shaping of a feeling of responsibility for community, and development of social sensitivity. Additionally, there is a need to clarify the following concepts, for example, the state, democracy, constitution, local and national election system, system of democratic institutions. The respondents also signaled a need for simulation games of the kind that can be used to show, for example, the election process in a gamified form.

The practice of the platforms and forms for students to express their opinions and especially the institutional decision-making process in schools are of special significance from the aspect of education for democracy in that both set an important example to be followed in terms of civic attitudes in adult life. The school administrators - in the context of an open question - pointed to teachers, in part, as well students, as an obstacle to the expansion and broadening of the sphere in which students can express their opinions. In the case of the students, they noted a lack of motivation, student disinterest and indifference, as well as the lack of a model for forming opinions; in the case of the teachers, reference was made rather to attitudes, as administrators said they are not open enough, unreceptive, and acknowledge students' opinions only with difficulty; as one teacher put it in an answer to an open-ended question about students: "Because of their age, expression of opinions is not one of their specific attributes, they are 
still ignorant and their critical thinking is underdeveloped." (Kalocsai, 2018). They delivered the assessment that, in this area, the tradition of students expressing their opinions has still not solidified, and both sides still have much to learn. At the same time, they gave no indication, in any manner or form, of how they, as administrators, could support the efficacy of the learning process in the interest of establishing more democratic school practices. The teachers named a lack of time, the volume of teaching materials, teachers' and students' workloads and the attitude of students as impediments to expanding students' expression of opinion; the students' responses also show that schools ask students' opinions in a relatively large number of areas (disciplinary matters, areas of school life: eating, breaks, etc.), - although the students gave the prevalence of the practice of expressing opinions even lower marks than did the teachers. Granted, the students' answers also indicate that "one can still talk to the teachers about anything in school" (Kalocsai, 2018). It sends a message that in matters related to the practice of teaching, for example selecting methods, applying learning organization solutions (principles of group learning, task distribution, etc.), and evaluating students' work, the opinions and preferences of teachers and students vary little. From this we could conclude that students would rather trust the administration/teachers to create the rules for the school's operation and the selection of the content and methods for classes, or they don't want to fight more actively for their interests in this area. Strictly speaking, the students have accepted that their mandate applies only to participating in school-level decisions related to school recreation (class trips, things related to school holidays, etc.) and to voting for student council members. However, they do insist on one thing: being involved in probes of injustice affecting their classmates, and being allowed a say in decision-making in these matters. With regard to the order of decision-making in schools, students are basically uninformed and don't really know which actors in schools are involved in various decision-making processes. It can be inferred that students don't feel they have a real opportunity to express their opinions in schools.

With regard to the operation of the student council (DÖK), there is a general understanding between teachers and students that the operation of the student council is of important significance from the aspect of school life. There is also no difference of opinion on the assumption that the effective operation of the student council can best serve education for democracy. But self-governance itself is interpreted in various manners, and with regard to the operation of the school, the diagnosis of students and teachers diverges on a number of points. The specific interpretation of self-governance indicates that the vast majority of school administrators/ teachers believe the most efficient manner for students to exercise their freedom of expression is in the organization of talks organized at the class level and the encouragement of the expression of opinions during lessons. They assessed the least effective tool to be school-level debates and reported that these took place least frequently in schools. Almost $40 \%$ of administrators did not agree that students should be allowed greater opportunity to have their say in school matters. Among youth, about $85 \%$ feel that student councils operate in a consequential manner. In contrast to school administrators, who believe that students' decisions and votes are the exclusive motivator for student council representatives, only one-third of young people are of the opinion that students' votes give legitimacy to student council leaders. Most believe the representatives of the student council have been picked by homeroom teachers and principals. Perhaps this can be explained by the survey results that show close to one-third of responding students don't know who their student council head is, and one-fourth only know the person by appearance, while $85 \%$ have never approached the DÖK regarding any problem or other matter. 
One-third of the students don't know the tasks of the DÖK in school, nor do they know which tasks, once completed, would improve its activities. The contradictory nature of the situation is also shown by the fact that few students know about the operation of the student council in their own school, while at the same time very clearly expressing the need, as a recommendation for improving school life, for more effective action by the student council in defending student rights, managing injustices involving students and mediating the stands of students. In parallel, insufficient effort is put into availing of opportunities student councils already have to participate in decision-making, for example, concerning house rules and - as mentioned earlier - the selection of classroom topics and applied methods, even though it is through these that requisite goals can be achieved most efficiently. The assumption/conclusion could be induced from this that students have only a rote understanding of what a real student council should be. Because they never, or hardly ever, are confronted with this in practice, they acknowledge the formal operation of the student council. They accept that the student council is a freetime organizer or in the best of circumstances - in the event a student suffers an injustice - it takes a so-called defensive role in school, but they do not expect it to have an important role in shaping the whole life of the school.

The picture revealed shows that even though there is probably a student council in every school, its operation is seen by teachers and students alike largely as a formality. All this creates a particular "democracy of appearances" in which there are the trappings of democracy, but the framework is not filled with any real content. It is likely that keeping the operation of the student council a formality is in some manner in the interest of both parties. It is perhaps in the teachers' interest because it makes their own self-image and conviction better fit for democratic orientation; and it benefits the students because - even though they have little say in school decisionmaking - the institution of the student council is utilized in "taking matters into one's own hands" (Jakab, 2018). The causes of the resulting situation are indeed multi-layered and complex - and can by no means be isolated from the operating paradigms of adult society - but what is certain is that it produces negative consequences both in the short and the long term.

Unfortunately, students cannot attend schools in which the preparation of every procedure, rule, curricular activity or other program involves their participation, thus these do not primarily serve their interests. They acknowledge the practice of decisions being made by higher powers without their participation. Because of this, they cannot experience in the scholastic framework the personal responsibility that comes with decision-making, the potential advantages found in cooperation with classmates, the order of complexity of difficult problems, and the compromises reached between conflicting sides with diverging interests through the methods of mediation, even though these can be, in practice, the real pillars of education for democracy.

The students answers to questions concerning the opportunities in school for education for citizenship attest, on the one hand, to their knowledge of conventions - preparation in school must contribute to education for citizenship (65\%), and our schools are equipped for this task and, on the other hand, a lack of understanding and passiveness with regard to public affairs and social solidarity. A relative majority (36\%) of respondents answered "I don't know" to the question of how schools can meaningfully contribute to education for democracy (Kalocsai, 2018). So-called community service and school volunteering, which demands personal activity, has been relegated to the background, and only invitations to schools of politicians and decisionmakers have a lower level of approval (The latter could be interpreted as an assessment of the credibility of figures in public life.) 
An examination of students' opportunities to be informed about public affairs shows a particular mix of shelteredness, isolation, disinterest, indifference and loss of hope. About two-thirds of students basically have no interest in public affairs or political issues. They not only are disinterested in politics, but also confess not to understanding topics related to public life. Almost $60 \%$ have nothing to say if political issues are brought up. Most get information about public life from the Internet and a smaller number from the television. Only about $25 \%$ of the age group are informed by their peers, even though among 13- to 16-yearolds, the age group's example-setting and socializing function is of important significance. Of greater concern appears to be the small proportion (10\%) of information related to public life that comes from teachers. If we also take into account that the relative majority (37\%) of students could not (or did not want to?) answer the question about opportunities to have a say in public affairs, validate their interests or affect change, and a further $29 \%$ thought they had no opportunity for this, then we may have diagnosed a picture that is indeed saddening. One-fourth of the respondents believe sharing their opinions with friends is an effective tool for having a say in public affairs, while just $13 \%$ said the same for voting and only $3 \%$ for signing a petition.

The picture shown by answers to questions related to the circumstances of public life are even more frustrating than that which appears with regard to the internal scholastic sphere. The responses show that instead of educating for conscious civic behavior (attitude), schools are educating students for political disinterest, social indifference and apathy. Not only are students unfamiliar with their political opportunities, the don't really want to get to know them, that is, they want to exercise the political rights they enjoy as adults - similar to the practice they learned in school - only in a formal manner. All of this results in a particular attitude of subordination which naturally entails the comfortable positioning of the prevailing power on society and the depletion of the democratic framework.

The answers mainly from primary school students confirm - what was already diagnosed in secondary schools - the inefficacy of political socialization and the attenuation of education for democracy (Csákó, 2018). It would appear that curricular materials as well as the atmosphere, microenvironment and space to take action - contrary to the stated goals - do not instill a desire for activity in public life, and two-thirds of teenage students have essentially given up on becoming adults who are active citizens interested in public affairs.

In educating for democracy, it should be a goal to establish the kind of institutional democratic atmosphere in which the "student's voice" can more strongly prevail. ${ }^{11}$ The childcentered approach is dominant; democratic classroom management is pedagogical practice which places emphasis on critical thinking and cross-disciplinary cooperation between individual teachers. The school's system of operation is regulated by a transparent - taking into account the consensus for the common interest - and intelligible decision-making mechanism. This kind of school practice would allow students to become active participants in the public life of the school, learn democratic rules and put into practice the processes and behavioral paradigms related to these rules in real-life circumstances, as well as recognize the necessity of taking into account common interests and the importance of results achieved through common effort.

\footnotetext{
${ }^{11}$ Student Voice Erasmus+ KA2 project (EKE OF 2016/17).
} 


\section{SUMMARY}

In the area of education for democracy and citizenship, international conventions as well as practices - especially if we view the matter in a European dimension - are moving away from the tradition of instructing for so-called "civil tasks" in the framework of a subject, while the complex, so-called whole school approach is increasingly gaining ground (Eurydice, 2018).

Pedagogical literature in Hungary - e.g. "The classroom teaching of democracy-related knowledge is, in itself, insufficient to turn students into democratically-minded citizens" (Csapó, 2000) - and even the official, often varying approach to regulation of curricular content - independent of diverging education policies - are in sync with international trends and clearly represent a modern approach to education for democracy. Unfortunately, everyday practice in schools shows a picture that is far from this, and it seems very remote that democratic education can be integrated into the institutional operation of schools in an overarching manner.

The aim of the survey was to identify development needs and not to provide a general or comprehensive picture of the state of education for citizenship in schools, thus it diagnosed primarily the contradictions between the principles established in the regulations and everyday practice. It would appear that the school's "veiled curriculum" overrides the approaches and systems of convention in the curriculum and requirements, convincing students "through everyday, almost subliminal messages" (Fülöp, 2009) not of the efficacy and reputation of selfconscious active participation in public affairs in cooperation and solidarity with peers, but rather of isolation, passiveness in public life, the simple truth of "least said, soonest mended", and the successful advancement of individual interests.

The resulting situation can be traced back to a number of reasons on different levels and of varying significance. Certainly students' perception of public life and their social well-being play a role. As does a decline in the commitment of the majority of society's members to a functioning democratic order in the past decades - in the context of the lack of economic recovery after the change of system. The public policy perception has also changed as the procedural perception of democracy has been replaced by the substantive perception; that is, the leader's commitment to the public good has become the main guarantee of democractive functioning, not democratic institutions or processes ${ }^{12}$ (Körösényi, 2004: 61-62).

Among these reasons must also be mentioned the changes the scholastic world has undergone in the past 25 years, changes which show a continuous weakening of the legal scope of power schools and teachers have to make decisions. First, the role of the teaching staff became a formality with the selection of school heads, then schools' autonomy in planning the local curriculum was reduced, and finally the restructuring of the system in which schools are managed - and measures related to this - practically depleted entirely communities of teachers' competency to make decisions. All of this resulted in a devaluation of teachers' function as mentors and practically forced on them the role of taskmaster. But it is difficult to educate an active, self-conscious and free, but responsible citizen while in the role of taskmaster. This is why it is an unavoidable and urgent task to restore the prestige of the teacher's profession as well as

\footnotetext{
${ }^{12}$ The concept of substantive democracy has often contributed to the ideological underpinnings of political dictatorships if the ability to recognize the common good is appropriated by some person or political group.
} 
professional autonomy over the functioning of schools. Naturally, while taking into account factors of fairness, effectiveness and efficiency.

It can only be hoped that the current circumstances do not become permanent, and that public and education policy, as well as schools and teachers - at least in their own sphere of influence - acknowledge the stakes in terms of socialization of these unfavorable processes and do all in their power to create the conditions for the systemic practice of education for democracy. The lack of this system of conditions is not only averse to the most habitable European traditions for the individual and the community and to the progressive center, it may also bring with it serious economic disadvantages in addition to social problems, and result in another "dead end" (Bibó, 1986a, 1986b). This is why it is important to be aware that educating children for democracy - similar to music - must begin at least "nine months before the mother gives birth", ${ }^{13}$ as the children embody the future.

Funding sources: No financial support was received for this study.

Author's contribution: This study is the unofficial byproduct of project EFOP-3.2.15-VEKOP17-2017-00001, a project aiming to help the development of thematic days and weeks, organized by the Educational Authority.

Conflict of interest: The author declares no conflict of interest.

\section{ACKNOWLEDGEMENTS}

I would like to thank my colleagues: Janka Kalocsai, for putting together the survey and preparing the report, and Zsolt Korpics, for all of his support in the development of the project.

\section{ABOUT THE AUTHOR}

Dr. habil. József Kaposi PhD. associate professor of the Pázmány Péter Catholic University Faculty of Arts and Social Sciences. Former research fellow of the National Institute of Public Education (OKI) and of the Institute for Educational Research and Development (OFI), where he was director general between 2011 and 2016. As a researcher and developer, he participated in the development of the Matura exam reform of 2005 and of the National Curricula (NAT, General curriculum) by providing professional guidance. His main fields of research are history didactics and civic education. Author of numerous textbooks and exercise books related to History teaching. His selected writings were published in two volumes, in 2015. He is a lecturer of the Vitéz János Teacher Training Department, where he is teaching pedagogy courses. At the Department he is responsible for the drama pedagogy and postgraduate teacher training. Currently he is the editor-in-chief of the New Pedagogical Review and editor of an online magazine called "History Teaching".website: http://kaposijozsef.hu/.

\footnotetext{
${ }^{13}$ Speech delivered by Zoltán Kodály at a conference on music education in 1948
} 


\section{REFERENCES}

Bibó, I. (1986a). Az európai társadalomfejlődés értelme [The meaning of European social development] In Válogatott tanulmányok. Harmadik kötet, 1971-1979. Budapest: Magvető Kiadó.

Bibó, I. (1986b). Eltorzult magyar alkat, zsákutcás magyar történelem [Distorted Hungarian Figure, Deadend Hungarian History] In Válogatott tanulmányok II. Budapest: Magvető Könyvkiadó.

Csákó, M. (2011). Állampolgárokat nevel-e az iskola? [Is the school educating citizens?] In B. Béla, \& S. Andrea (Eds.), Arctalan (?) nemzedék. Ifjúság 2000-2010. Budapest, Nemzeti Család- és Szociálpolitikai Intézet.

Csákó, M. (2018). Politikai szocializáció serdülőkorban [Political Socialization in Adolescence]. Metszetek, 27-42, 2018/3/1. http://metszetek.unideb.hu/files/metszetek_201803_07_csako.pdf (April 26, 2019).

Csapó, B. (2000). Az oktatás és a nevelés egysége a demokratikus gondolkodás fejlesztésében [The Unity of Instruction and Education in the Development of Democratic Thinking]. Új Pedagógiai Szemle, 24-34, February.

Eurydice. (2012). Citizenship education in Europe. Education, Audiovisual and Culture Executive Agency.

Eurydice. (2017). Citizenship education at school in Europe 2017. Eurydice report. Education, Audiovisual and Culture Executive Agency.

Eurydice. (2018). Citizenship education at school in Europe 2018. Eurydice report. Education, Audiovisual and Culture Executive Agency.

Falus, K., \& Jakab, G. (2006). Aktív állampolgárságra nevelés. [Education for active citizenship] In K. Kinga (Eds.), A kompetencia. Budapest: Országos Közoktatási Intézet.

Fülöp, M. (2009). Az együttmüködő és versengő állampolgár nevelése. [Education of the cooperative and competitive citizen]. Iskolakultúra. No. 3-4.

Gazsó, F., \& Stumpf, I. (Eds.) (1995). Vesztesek - Ifjúság az ezredfordulón. [Losers - Youth of the millennium]. Budapest, Ezredforduló Alapítvány.

Gönczöl, E. (2001). Állampolgári ismeretek. [Civics] In K. Imre (Ed.), Az évszámokon innen és túl. Megújuló történelemtanitás. Budapest: Műszaki Könyvkiadó.

Gunst P. (Ed.). (1996). Európa története. [The history of Europe]. Debrecen, Csokonai Kiadó.

Halász G. (2005). Demokráciára és aktív állampolgárságra nevelés a 21. században. [Education for democracy and active citizenship in the 21st century]. Új Pedagógiai Szemle, July-August.

Huddleston, T., \& Rowe, D. (2002). Állampolgárságra és demokráciára nevelés az angol iskolákban. [Education for Citizenship and Democracy in English Schools] Új Pedagógiai Szemle, March.

Jakab, G. (2018). Bevezetés a demokratikus állampolgári nevelés iskolai integrációs problémáinak diszkurzív vizsgálatára. [Introduction to a Discursive Examination of the Problems of Integrating Education for Democracy into Schools]. PhD dissertation (manuscript).

Kalocsai, J. (2018). Gyorsjelentés a Demokrácia kérdöívröl [Report on a democracy questionnaire]. Manuscript.

Kaposi, J. (2013). A tartalmi szabályozás hazai változásai. [Hungarian versions of content regulation] Új Pedagógiai Szemle, 63(9-10), 14-37.

Kaposi, J. (2015). Állampolgárságra, demokráciára nevelés. [Education for citizenship, democracy] In K. Kaposi, Válogatott tanulmányok (pp. 135-152). Budapest: Szaktudás Kiadó Ház Zrt.

Körösényi, A. (2004). Kormányzati rendszerek. [Government systems] In J. Gyurgyák (Ed.), Mi a politika? Bevezetés a politika világába. Budapest, Osiris Kiadó.

Kinyó L. (2012). Az állampolgári kompetencia egyes összetevőinek és a közösségi tevékenységformák jellemzöinek vizsgálata 7. és 11. évfolyamos tanulók körében. [PhD dissertation: Individual Components of 
the Competence of Citizenship and an Examination of the Characteristics of Forms of Community Activities Among Students in the 7th to 11th Grades].

Mátrai, Z. (1999). In transit. Civic education in Hungary. In J. Torney-Purta, J. Schwille, \& J. Amadeo (Eds.), Civic education across countries: Twenty-four national case studies from the IEA Civic Education Project. Amsterdam: IEA.

Reference framework of competences for democratic culture. Volume 1-3. Council of Europe, 2018. Volume 1 - Context, concepts and model: https://rm.coe.int/prems-008318-gbr-2508-referenceframework-of-competences-vol-1-8573-co/16807bc66c [8 December 2018]. Volume 2 - Descriptors of competences for democratic culture. https://rm.coe.int/prems-008418-gbr-2508-reference-frameworkof-competences-vol-2-8573-co/16807bc66d [8 December 2018]. Volume 3 - Guidance for implementation https://rm.coe.int/prems-008518-gbr-2508-reference-framework-of-competences-vol-38575-co/16807bc66e [8 December 2018].

Stevenson, J. (Ed.) (2005. History of Europe. Budapest: Kossuth Publishers.

Strategy. (2009). Draft committee members: Falus, Katalin, Galambos, Rita, Kende, Ágnes, Mihály, Ottó, Setényi, János, \& Szelényi, Zsuzsa.

Szabó, M. (2016). Discursive political science. Introduction to the interpretive approach to and research of politics. Budapest, Osiris Publishers.

Szücs, J. (1983). Sketch of Europe's three historical Regions. Accelerating time Series. Budapest, Magvetö Publishers. Vágó, I., \& Vass, V. (1996). The content of education. In G. Halász, \& J. Lannert (Eds.). Report on Hungarian public education 2006 (pp. 197-278). Budapest: National Institute of Public Education. Weber, M. (2020). The protestant ethic and the spirit of capitalism. L. Harmattan Könyvkiadó Kft.

\section{LEGAL REFERENCES}

100/1997. (VI. 13.) Korm. rendelet az érettségi vizsga vizsgaszabályzatának kiadásáról.

40/2002. (V. 24) Korm. rendelet az érettségi vizsga részletes követelményeiről.

243/2003. (XII.17.) Korm. rendelet a Nemzeti Alaptanterv kiadásáról.

202/2007. (VII. 31.) Korm. rendelet a Nemzeti Alaptanterv kiadásáról, bevezetéséról és alkalmazásáról.

8/2013. (I. 30.) EMMI rendelet a tanári felkészítés közös követelményeiről és az egyes tanárszakok képzési és kimeneti követelményeiröl.

NAT 1995 Művelődési és Közoktatási Minisztérium, Korona Kiadó 1995

Open Access. This is an open-access article distributed under the terms of the Creative Commons Attribution 4.0 International License (https://creativecommons.org/licenses/by/4.0/), which permits unrestricted use, distribution, and reproduction in any medium, provided the original author and source are credited, a link to the CC License is provided, and changes - if any - are indicated. (SID_1) 